\title{
Genetic diversity and population structure of the threatened temperate woody bamboo Kuruna debilis (Poaceae: Bambusoideae: Arundinarieae) from Sri Lanka based on microsatellite analysis ${ }^{\dagger}$
}

\author{
Lakshmi Attigala*, Timothy Gallaher, John Nason and Lynn G. Clark \\ Department of Ecology, Evolution and Organismal Biology, College of Liberal Arts and Sciences, Iowa State University, 251 Bessey Hall, Ames, \\ IA, 50011-1020, USA.
}

\begin{abstract}
Species of the temperate woody bamboo genus Kuruna Attigala, Kathriar. \& L.G. Clark (Poaceae: Bambusoideae) distributed in Sri Lanka and southern India, are threatened due to deforestation and habitat fragmentation. The current study focused on the tetraploid woody bamboo Kuruna debilis (Thwaites) Attigala, Kathriar. \& L.G. Clark, using twelve variable microsatellite loci to assess the genetic diversity and population structure in six known Sri Lankan populations. Due to the rarity of the species, an exhaustive sampling of accessible plants resulted in a total of only 28 individuals. Nonetheless, the allelic diversity was high at most loci and given the limited distances separating populations $(<65 \mathrm{~km}$ apart), they exhibited a fairly high genetic differentiation $\left(\mathrm{F}_{\mathrm{ST}}=0.113\right)$ and strong isolation by distance. Structure, neighbour-joining, and neighbour-net analyses concur in grouping the six $K$. debilis populations into three genetic clusters consistent with the spatial proximity of the populations: one cluster comprised populations from the Piduruthalagala Mountain and Horton Plains, the second cluster consisted of the population from Adams Peak and the last comprised the populations from the Handapan Ella Plains. Due to multiple indicators of high allelic diversity, the population from the northern Horton Plains (LA124) should be targeted for conservation. Moreover, the population found in Adams Peak (LA159) is also genetically important and critical to the conservation of these species due to its unique genetic diversity. As the first population genetics study of Bambusoideae in Sri Lanka, we anticipate that our results will provide a foundation for future comparative population genetics and conservation studies in the country.
\end{abstract}

Keywords: Kuruna debilis, microsatellites, population genetics, Sri Lanka.

\section{INTRODUCTION}

Bamboos (subfamily Bambusoideae, Poaceae) are an essential component of forest and tropical high altitude grassland ecosystems worldwide (Soderstrom \& Calderón, 1979; Judziewicz et al., 1999; Clark et al., 2015). In Sri Lanka, bamboos occur naturally in all three major climatic zones (Wet, Dry and Intermediate); however, no native bamboo is found in extremely dry areas (Kariyawasam, 1998). Bamboo, in general, is an economically, culturally and ecologically important plant for Sri Lanka (De Zoysa \& Vivekanandan, 1994; Gunatilleke et al., 1994). Most of the non-native bamboos are used in housing and construction due to their enduring, versatile and highly renewable nature. There are no statistics on bamboo consumption, but the forestry sector master plan (FSMP) of Sri Lanka estimated that the total annual consumption was at least $80,000 \mathrm{~m}^{3}$, i.e. about 700,000 culms two decades ago (FSMP, 1995). Although the native bamboos are not of economic importance, their ecological value is significant. One such example is the animal biodiversity associated with the native bamboos such as the Sambar deer, many insects and fungi (Abayasinghe et al., 2014; personal observations). Bamboo studies conducted in Sri Lanka have mainly focused on its reproductive ecology (Ramanayake \& Yakandawala, 1995; 1998; Ramanayake \& Weerawardene, 2003), vegetative propagation (Ramanayake et al., 2001; 2007) and growth and development (Rajapakse, 1992; Ramanayake et al., 2001).

\footnotetext{
“Corresponding author (lakshmi@iastate.edu)

$\dagger$ This material was presented at Botany 2014, Boise, Idaho, USA
} 
Bamboos, with over 1500 species worldwide, are classified in three tribes, the tropical woody Bambuseae, the temperate woody Arundinarieae and the herbaceous Olyreae (Clark et al., 2015). A recent study revealed that all of the native Sri Lankan temperate woody bamboos along with the south Indian species form a major lineage in the Arundinarieae resulting in the recognition of the genus Kuruna (Attigala et al., 2014). To date, there are seven species in this genus including two endemic Sri Lankan species $[K$. scandens (Soderstr. \& R.P. Ellis) Attigala, Kathriar. \& L.G. Clark and K. serrulata Attigala Kathriar. \& L.G. Clark], one species endemic to south India [Kuruna wightiana (Nees) Attigala, Kathriar. \& L.G. Clark], and four species [K. debilis; K. densifolia (Munro) Attigala, Kathriar. \& L.G. Clark; K. floribunda (Thwaites) Attigala, Kathriar. \& L.G. Clark; K. walkeriana (Munro) Attigala, Kathriar. \& L.G. Clark] occurring in both Sri Lanka and South India (Seethalaksmi \& Muktesh Kumar, 1998; Muktesh Kumar, 2011; Attigala et al., 2014; 2016).

The indigenous flowering plants of Sri Lanka include about 3,156 species (Wijesundara et al., 2012). Nearly one fourth of these are endemic and concentrated in the humid southwestern quarter of the country (Gunatilleke \& Gunatilleke, 1990). For many years, forests in Sri Lanka have been cleared both legally and illegally, due to the rapidly increasing demand for land for settlement schemes, timber production, economic and agricultural developments and weak enforcement of land use policies in the country (Gunatilake, 1998; Government of Sri Lanka, 2000; Bandaratillake \& Fernando, 2003). Several studies have reported that the closed-canopy forest cover has decreased from $84 \%$ in 1884 to approximately $19 \%$ in 2005 (Nanayakkara, 1996; FAO, 2005). Thus, deforestation can negatively influence the survival of the threatened and endemic flora and fauna in Sri Lanka. Many plant molecular studies have shown that habitat fragmentation and small population size may negatively influence the genetic diversity of populations (Ellstrand \& Elam, 1993; Fischer \& Matthies, 1998; Luijten et al., 2000; Paschke et al., 2002). Low levels of genetic diversity typically limit the ability of a population to adapt to adverse environmental conditions or increased competition (Fischer et al., 2000; Pluess \& Stocklin, 2004). Each of the Kuruna species found in Sri Lanka has a limited distributional range (populations $<65 \mathrm{~km}$ apart) and therefore, may be under severe threat due to deforestation and habitat fragmentation. Of the six native Kuruna species, only $K$. debilis has several, spatially distinct populations in the understory of the upper cool mountain slopes of Sri Lanka's Central Province (elevation: 1500 - 2500 m).
Based on herbarium records $K$. debilis populations are found at the Adams Peak, Horton Plains, Piduruthalagala Mountain, Knuckles Mountains and the Handapan Ella Plains of Sri Lanka. Muktesh Kumar (2011) reported that $K$. debilis has also been located recently from the Kerala part of the Western Ghats, but provided no documentation. The other five species ( $K$. densifolia, $K$. floribunda, $K$. scandens, $K$. serrulata and $K$. walkeriana) are each restricted to $1-2$ populations on a few mountain summits and in open montane grasslands in Sri Lanka (Figure 1). Due to their restricted distribution and habitat loss related to human activities, these five species are already at risk. Population genetic studies are essential for planning conservation strategies for these Kuruna species. Such studies provide conservation managers with significant information concerning elevated levels of random genetic drift and inbreeding, and reduced inter-population gene flow and genetic estimates of these processes could potentially be used to initiate conservation planning (Ellstrand \& Elam, 1993; Young et al., 1996).

The primary objective of this study was to assess the genetic diversity and population structure in six natural populations of the tetraploid woody bamboo K. debilis in Sri Lanka.

\section{METHODOLOGY}

\section{Population sampling}

Leaf samples were collected from 28 individual plants from 6 different geographic localities, mainly from 3 remote montane forests and an open montane grassland (Figure 1). Of the 5 main localities of $K$. debilis populations (Adams Peak, Horton Plains, Piduruthalagala Mountain, Knuckles Mountains and Handapan Ella Plains), the authors were able to collect population samples from all localities except the Knuckles Mountains. Although a collection trip was made to Knuckles Mountains we were unable to locate any K. debilis populations. Kuruna debilis has a pachymorph rhizome system resulting in densely packed culms that can occupy a relatively large area. Due to clonal propagation, it is difficult in the field to differentiate individuals at a particular locality because a simple 'head count' may not reveal the true number of genets, or genetic individuals in a population. Therefore, samples were collected from individuals that were readily distinguishable as a single plant and all propagating clones of an individual plant were considered as a single entity to allow for a number of statistically significant results. 


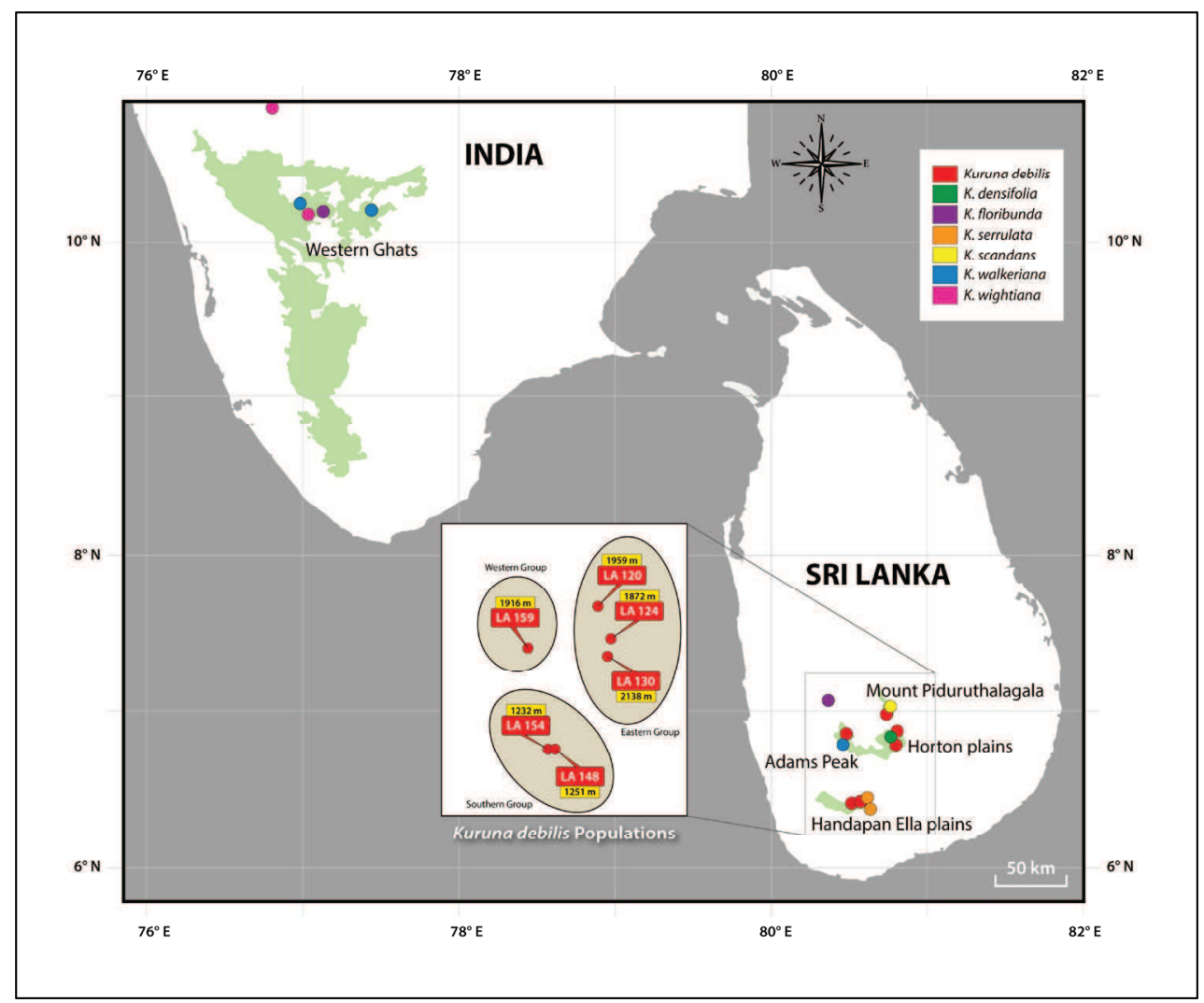

Figure 1: Distribution of Sri Lankan Kuruna species. Colours indicate different Kuruna species. The numbers in each box indicate the elevation for that population and the six $K$. debilis populations with their genetic clustering.

Map source: Wikipedia (http://en.wikipedia.org/wiki/Sri_Lanka\#mediaviewer/File:Topography_ Sri_Lanka.jpg)

\section{Marker selection}

Microsatellite sequences (SSRs) are highly polymorphic and readily replicable markers, evenly distributed throughout eukaryotic genomes. Based on previous studies on temperate woody bamboos (Kitamura et al., 2009; Zhan et al., 2009), 25 primer pairs were tested with a subset of samples to evaluate successful amplification. Of the 25 microsatellite primers, 12 were successfully amplified and selected for the study (Table 1).

\section{DNA extraction and genotyping}

Total genomic DNA extractions were performed from silica gel-dried specimens using the Iowa State University DNA Facility's Autogenprep 740 DNA extraction robot. Genotyping was performed on an ABI
3730 DNA analyser (Perkin-Elmer, Applied Biosystems Division, Norwalk, Connecticut) by the DNA Sequencing Facility at the Iowa State University. All PCR and cyclesequencing reactions were performed in an MJ Research PTC-200 thermal cycler. PCR was performed in $25 \mu \mathrm{L}$ volumes. The amplification products were cleaned using polyethylene glycol (PEG 6000) precipitation to remove unincorporated primers and dNTPs from the PCR products. Genotyping of microsatellite loci were subjected to standard error checking procedures, as described in DeWoody et al. (2006).

Individual tetraploid genotypes were scored from the electropherograms following the microsatellite DNA allele counting-peak ratios (MAC-PR) method of Esselink et al. (2004) using the GeneMapper ${ }^{\circledR}$ v4.1 (Applied Biosystems) software. 


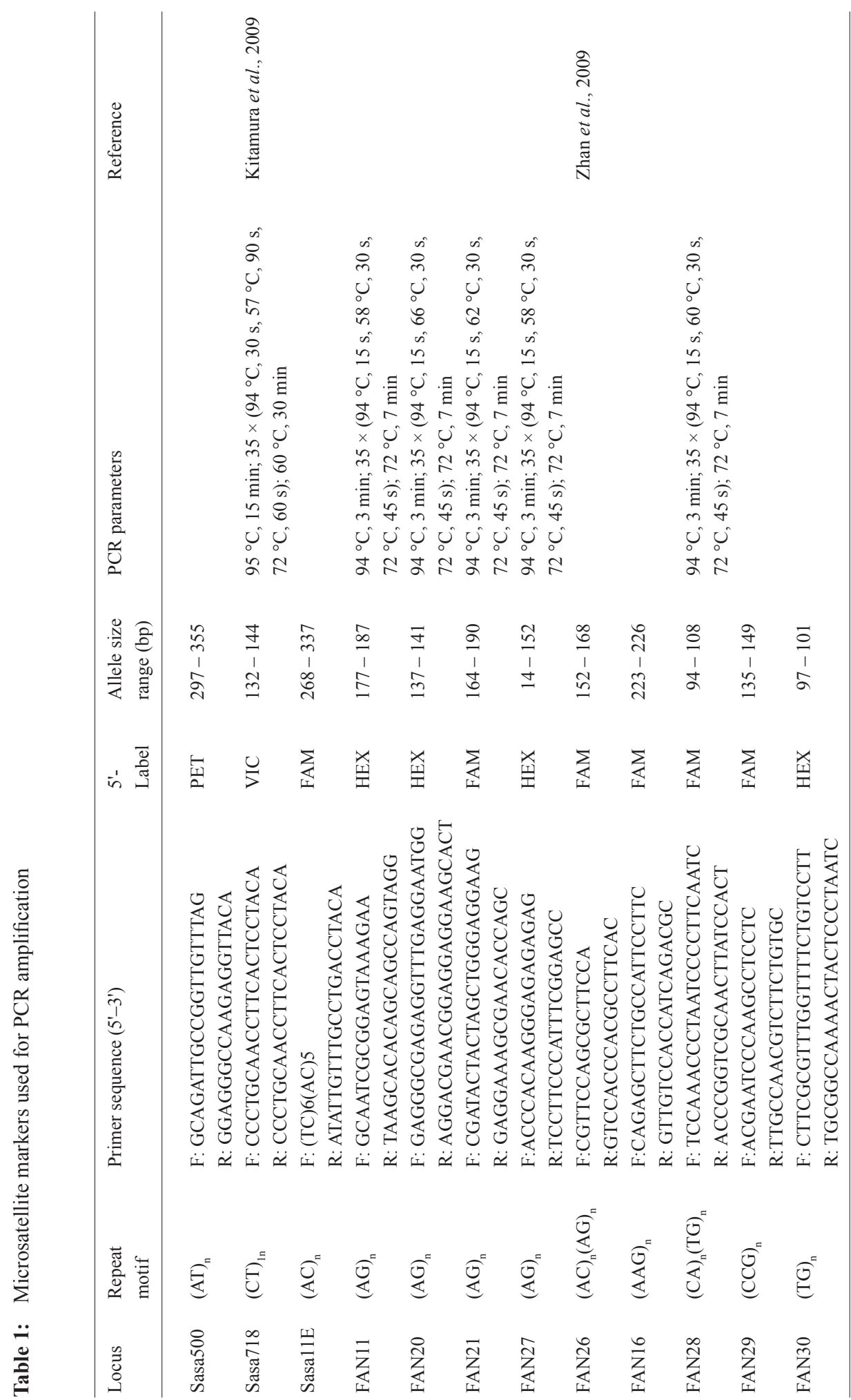

\section{Genetic data analysis}

The software SPAGeDi 1.4c (Hardy \& Vekemans, 2002) was used to compute the percentage of missing genotypes and the following estimates of genetic diversity: the number of alleles per locus $\left(\mathrm{N}_{\mathrm{A}}\right)$; the effective number of alleles $\left(\mathrm{N}_{\mathrm{Ae}}\right)$ estimated following Nielsen et al. (2003); rarefied allelic richness $\left(A_{R}\right)$ expressed as the expected 
number of alleles among $\mathrm{k}$ gene copies (12 gene copies for the current study); and the expected heterozygosity corrected for sample size $\left(\mathrm{H}_{\mathrm{e}}\right)$. These measures and the inbreeding coefficient $\left(\mathrm{F}_{\mathrm{IS}}\right)$ were estimated for each locus and each $K$. debilis population. The $\mathrm{A}_{\mathrm{R}}$ used in the current study is corrected for variation in sample size by using the rarefaction method recommended for uneven sample sizes (Hurlbert, 1971; Petit et al., 1998). Further, global F-statistics $\left(\mathrm{F}_{\mathrm{IT}}, \mathrm{F}_{\mathrm{IS}}\right.$ and $\mathrm{F}_{\mathrm{ST}}$ ) were estimated over all loci and populations using SPAGeDi 1.4c (Hardy \& Vekemans, 2002) with the significance of average values determined by permutation $(10,000$ replicates). The observed heterozygosity $\left(\mathrm{H}_{\mathrm{o}}\right)$ was calculated manually for each population over all loci.

The spatial genetic structure was inferred using a Bayesian clustering approach, which was implemented in Structure 2.3.4 (Pritchard et al., 2000). The model parameters were set to admixture with correlated allele frequencies between populations, and 20 replicated runs were performed for each value of $\mathrm{K}$ (the number of clusters) spanning from $1-5$. The burn-in was set to 100,000 followed by 200,000 recorded Markov Chain Monte Carlo steps. Each run estimated the log probability of data, $\mathrm{L}(\mathrm{K})$. Following Evanno et al. (2005), the differences in $\log \mathrm{L}(\mathrm{K})$ for successive values of $\mathrm{K}(\Delta \mathrm{K})$ were used to determine the most likely number of clusters, a process implemented using the Structure Harvester (Earl \& vonHoldt, 2012). The preferred value of $\mathrm{K}$ using this method is the one associated with the highest value of $\Delta \mathrm{K}$. The $\mathrm{K}$ repetitions were permuted in the software CLUMPP 1.1.2 (Jakobsson \& Rosenberg, 2007) and results were graphically represented using the software DISTRUCT 1.1 (Rosenberg, 2004).

Population differentiation was assessed by analysis of molecular variance (AMOVA) using the software ARLEQUIN v3.5.1.2 (Excoffier et al., 2005). The $\mathrm{K}$ optimal genetic clusters detected with Structure determined the hierarchical levels in the AMOVA analysis and resulted in three estimates of genetic differentiation: $\Phi_{\text {ST }}$, genetic differentiation among subpopulations relative to the total population; $\Phi_{\mathrm{SC}}$, genetic differentiation among subpopulations within a genetic cluster; and $\Phi_{\mathrm{CT}}$, genetic differentiation among genetic clusters relative to the total population. The significance of $\Phi$-values was determined by permutation $(10,000$ replicates). Isolation by distance (IBD) was evaluated by assessing the correlation between the log transformed genetic distance measure $\mathrm{F}_{\mathrm{ST}} /\left(1-\mathrm{F}_{\mathrm{ST}}\right)$ (Rousset, 1997) and geographic distance, with significance determined by the Mantel test in the programme IBDWS 3.22 (Jensen et al., 2005). For the IBD analyses, geographic distances were calculated manually. The significance was based on 10,000 permutation replicates. For both AMOVA and IBD analyses, the tetraploids were treated as diploids (Saltonstall, 2003) as there was no evidence of inbreeding within populations of $K$. debilis and also the analysis programmes allowed only diploid or haploid data. The diploid data matrix was generated by randomising the genotypes within each population.

A rooted majority rule consensus tree was constructed using the neighbour-joining (NJ) method with CavalliSforza and Edward's chord distance (Cavalli-Sforza \& Edward, 1967). The distances and the NJ tree were generated using a combination of SEQBOOT, GENDIST, NEIGHBOUR, and CONSENSE modules in PHYLIP v. 3.695 (Felsenstein, 1989). The temperate woody bamboos Oldeania alpina (K. Schum.) Stapleton and Chimonocalamus montanus J.R. Xue \& T.P. Yi were used as outgroups to root the NJ tree. The resulting NJ tree was visualised with FigTree software v1.4 (http:// tree.bio.ed.ac.uk/software/figtree/).

As further means of visualising the genetic clustering of sample populations, a network-building distancebased algorithm (Neighbour-Net) was performed with SplitsTree4 v. 4.13.1 (Huson \& Bryant, 2006) based on the Cavalli-Sforza and Edward's chord distance obtained from GENDIST in PHYLIP v. 3.695 (Felsenstein, 1989).

\section{RESULTS}

\section{Allelic variation at microsatellite loci}

All twelve microsatellite loci assayed were polymorphic, and the number of alleles detected for each locus varied between 3 (FAN30) to 20 (Sasa500) leading to 94 alleles observed in total with $2.7 \%$ missing genotypes. These selected loci on average generated 8 alleles per locus and an expected heterozygosity of 0.708 . Table 2 summarises the genetic diversity of the 12 microsatellite loci.

\section{Genetic variation within populations}

Despite the small number of plants available within populations ( $3-5$ individuals), measures of average genetic diversity were relatively high (Table 3 ). For individual populations, the average per-locus number of alleles, rarefied allelic richness, and effective number of alleles were $\mathrm{N}_{\mathrm{A}}=4.08$ (range $3.33-4.75$ ), $\mathrm{A}_{\mathrm{R}}=3.75$ $(3.09-4.32)$ and $\mathrm{N}_{\mathrm{Ae}}=3.67(2.74-4.25)$, respectively. Populations 1 (LA120) and 6 (LA159) consistently had the lowest levels of allelic diversity, while values for populations 2 (LA124) and 5 (LA 154) were consistently the highest. Similarly, for each population, the average 
observed heterozygosity $\left(\mathrm{H}_{\mathrm{O}}\right)$ and the average expected heterozygosity corrected for sample size $\left(\mathrm{H}_{\mathrm{e}}\right)$ were 0.758 (range $0.633-0.834$ ) and 0.708 (range $0.533-0.712$ ), respectively. Except for the population at Adams Peak
(LA159), all the other populations showed deficits in heterozygotes (average $\mathrm{F}_{\mathrm{IS}}=0.170$; range $0.175-0.012$ ). However, the LA159 population showed an excess of heterozygotes $\left[\mathrm{F}_{\mathrm{IS}}=-0.024\right.$ (Table 3$\left.)\right]$.

Table 2: Locus-level and average measures of genetic diversity for 12 microsatellite loci genotyped across six $K$. debilis populations

\begin{tabular}{lcccccc}
\hline Locus & $\begin{array}{c}\text { Sample } \\
\text { size }\end{array}$ & $\begin{array}{c}\text { Percentage of } \\
\text { missing genotypes }\end{array}$ & $\mathrm{N}_{\mathrm{A}}$ & $\mathrm{N}_{\mathrm{Ae}}$ & $\mathrm{H}_{\mathrm{e}}$ & $\mathrm{H}_{\mathrm{O}}$ \\
\hline Sasa500 & 28 & 0 & 20 & 7.71 & 0.871 & 0.678 \\
Sasa718 & 28 & 0 & 7 & 5.40 & 0.815 & 0.900 \\
Sasa11E & 28 & 0 & 4 & 3.15 & 0.683 & 0.967 \\
FAN11 & 28 & 3.6 & 6 & 4.95 & 0.798 & 0.845 \\
FAN16 & 28 & 7.1 & 2 & 1.88 & 0.468 & 0.567 \\
FAN20 & 28 & 0 & 7 & 3.33 & 0.700 & 0.678 \\
FAN21 & 28 & 0 & 10 & 5.99 & 0.833 & 1.000 \\
FAN26 & 28 & 0 & 9 & 4.11 & 0.757 & 0.870 \\
FAN27 & 28 & 21.4 & 7 & 3.49 & 0.714 & 0.767 \\
FAN28 & 28 & 0 & 7 & 4.60 & 0.783 & 1.000 \\
FAN29 & 28 & 0 & 12 & 4.86 & 0.794 & 0.588 \\
FAN30 & 28 & 0 & 3 & 1.40 & 0.284 & 0.245 \\
Average over & 28 & 2.7 & 7.83 & 4.24 & 0.708 & 0.758 \\
all loci & & & & & & \\
\hline
\end{tabular}

$\mathrm{N}_{\mathrm{A}}$ : number of alleles with non-zero frequency; $\mathrm{N}_{\mathrm{Ae}}$ : effective number of alleles; $\mathrm{H}_{\mathrm{e}}$ : expected heterozygosity corrected for sample size; $\mathrm{H}_{\mathrm{O}}$ : observed heterozygosity

Table 3: Measures of genetic diversity for each of the six populations of $K$. debilis averaged across 12 microsatellite loci

\begin{tabular}{llcccccccc}
\hline Population & Locality & $\begin{array}{c}\text { Sample } \\
\text { Size }\end{array}$ & $\begin{array}{c}\text { Percentage } \\
\text { of missing } \\
\text { genotypes }\end{array}$ & $\mathrm{N}_{\mathrm{A}}$ & $\mathrm{N}_{\mathrm{Ae}}$ & $\mathrm{A}_{\mathrm{R}}$ & $\mathrm{H}_{\mathrm{e}}$ & $\mathrm{H}_{\mathrm{O}}$ & $\mathrm{F}_{\mathrm{IS}}$ \\
\hline $\begin{array}{l}\text { Population 1 } \\
\text { (LA120) }\end{array}$ & $\begin{array}{l}\text { Piduruthalagala } \\
\text { Mountain }\end{array}$ & 5 & 1.7 & 3.33 & 2.74 & 3.09 & 0.533 & 0.633 & 0.175 \\
$\begin{array}{l}\text { Population 2 } \\
\text { (LA124) }\end{array}$ & $\begin{array}{l}\text { Horton Plains } \\
\text { (north) }\end{array}$ & 5 & 6.7 & 4.75 & 4.25 & 4.32 & 0.695 & 0.767 & 0.152 \\
$\begin{array}{l}\text { Population 3 } \\
\text { (LA130) }\end{array}$ & $\begin{array}{l}\text { Horton Plains } \\
\text { (south) }\end{array}$ & 5 & 1.7 & 4.50 & 3.81 & 3.93 & 0.632 & 0.750 & 0.042 \\
$\begin{array}{l}\text { Population 4 } \\
\text { (LA148) }\end{array}$ & $\begin{array}{l}\text { Handapan Ella } \\
\text { Plains }\end{array}$ & 3 & 0 & 3.83 & 4.01 & 3.83 & 0.712 & 0.834 & 0.119 \\
$\begin{array}{l}\text { Population 5 } \\
\text { (LA154) }\end{array}$ & $\begin{array}{l}\text { Handapan Ella } \\
\text { Plains }\end{array}$ & 5 & 1.7 & 4.67 & 4.25 & 4.17 & 0.665 & 0.800 & 0.012 \\
$\begin{array}{l}\text { Population 6 } \\
\text { (LA159) }\end{array}$ & Adams Peak & 5 & 3.3 & 3.42 & 2.94 & 3.18 & 0.570 & 0.767 & -0.024 \\
$\begin{array}{l}\text { Multilocus } \\
\text { Average: all } \\
\text { populations } \\
\text { combined }\end{array}$ & & & & & & & & & \\
\hline
\end{tabular}

$\mathrm{N}_{\mathrm{A}}$ : number of alleles with non-zero frequency; $\mathrm{N}_{\mathrm{Ae}}$ : effective number of alleles; $\mathrm{A}_{\mathrm{R}}$ : rarefied allelic richness; $\mathrm{H}_{\mathrm{e}}$ : expected heterozygosity corrected for sample size; $\mathrm{H}_{\mathrm{O}}$ : observed heterozygosity; $\mathrm{F}_{\mathrm{IS}}$ : inbreeding coefficient 


\section{Population genetic structure}

The proportion of the observed genetic variation between clusters ranged from $\mathrm{F}_{\mathrm{ST}}=-0.053$ for locus FAN27 to 0.394 for locus FAN30 with an average value of 0.113 that was significantly greater than zero $(\mathrm{p}<0.001$; Table 4). Individual locus estimates of the inbreeding coefficient $\left(\mathrm{F}_{\mathrm{IS}}\right)$ ranged from - 0.055 (FAN26) to 0.414 (FAN29) with a mean of $0.078(\mathrm{p}<0.001$; Table 4$)$.

Structure analyses using the Evanno method in Structure Harvester grouped the six populations into $\mathrm{K}=3$ clusters (Figures 2 and $3 \mathrm{~A}$ ). The estimated population structure inferred for $\mathrm{K}=2-5$ has been shown in Figure 3A. The three clusters correspond well to the geographic distribution of the populations (Figure 1), with populations 1, 2 and 3 (LA120, LA124 and LA130) forming an Eastern cluster, populations 4 and 5 (LA148 and LA154) a Southern cluster, and population 6 (LA159) a Western cluster (Figure 3A). The populations in the Eastern cluster were sampled from the Piduruthalagala Mountain (LA120) and the Horton Plains (LA124 and LA130). These two localities are in relatively close proximity and are separated by ca. $15 \mathrm{~km}$. The two populations in the Southern cluster are from Handapan Ella Plains and Western cluster is from Adams Peak.
A

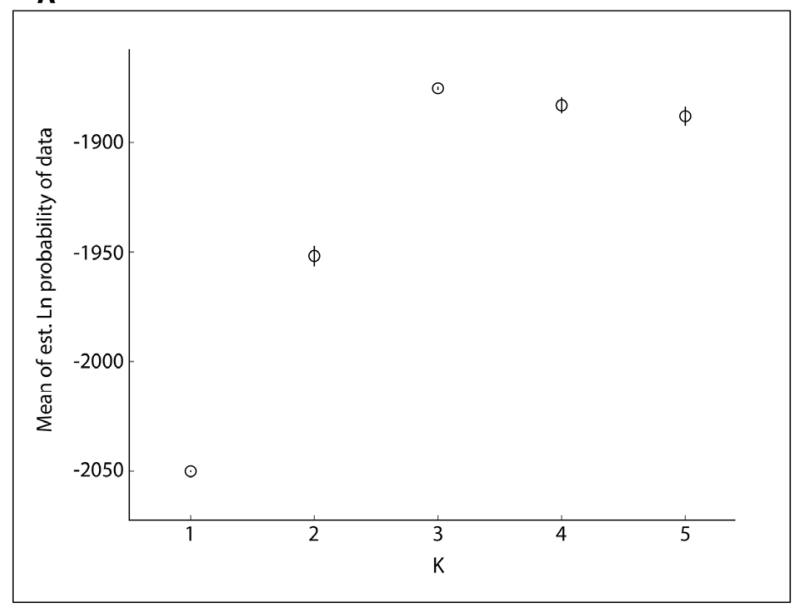

C

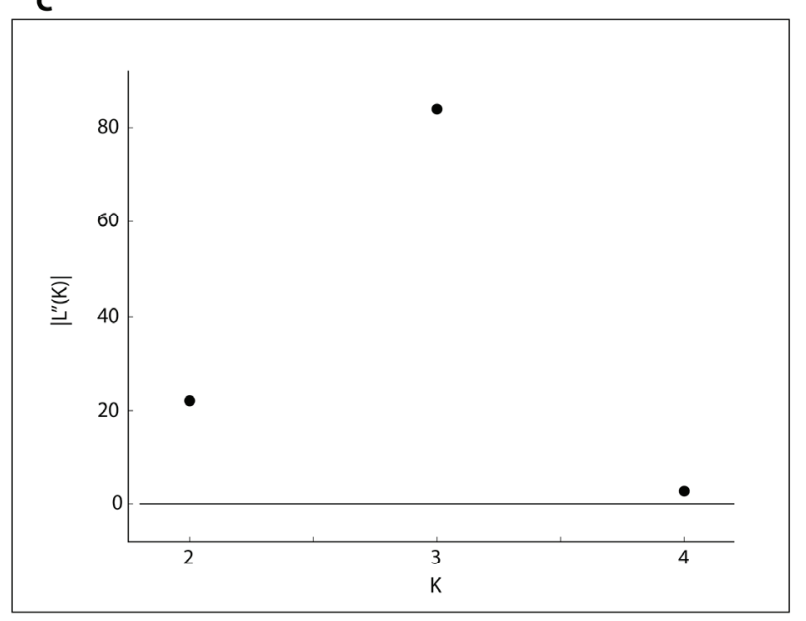

B

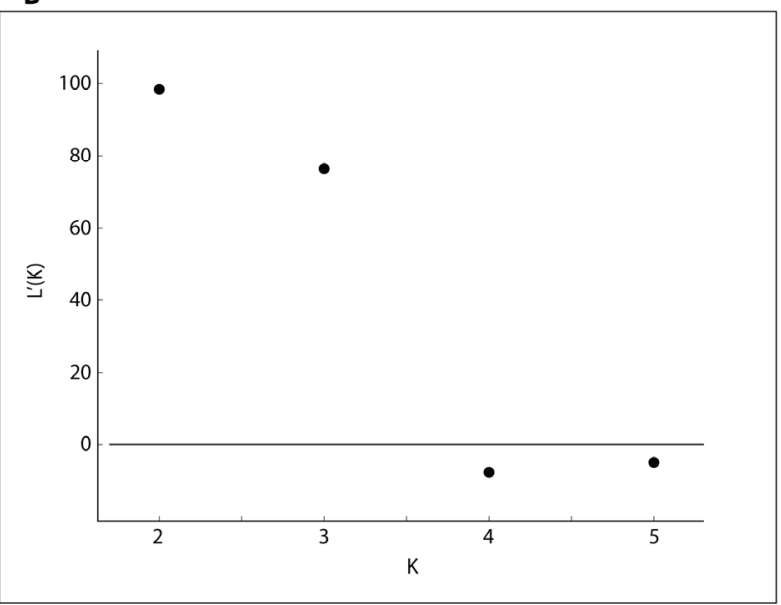

D

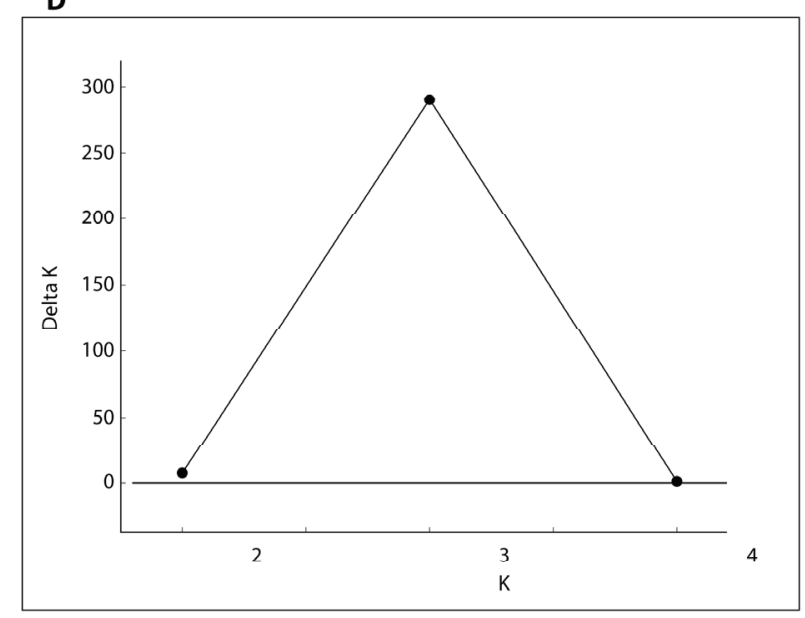

Figure 2: Structure Harvester results of structure analyses for $\mathrm{K}=2-5$ putative genetic clusters of $K$. debilis individuals. A: mean $\mathrm{L}(\mathrm{K})$ $( \pm \mathrm{SD})$ over 20 runs for each $\mathrm{K}$ value; $B$ : rate of change of the likelihood distribution (mean $\pm \mathrm{SD}$ ) calculated as $\mathrm{L}^{\prime}(\mathrm{K})=\mathrm{L}(\mathrm{K})-$ $\mathrm{L}(\mathrm{K}-1)$; $\mathrm{C}$ : absolute values of the second order rate of change of the likelihood distribution (mean $\pm \mathrm{SD}$ ) calculated according to the formula: $\left|\mathrm{L}^{\prime \prime}(\mathrm{K})\right|=\left|\mathrm{L}^{\prime}(\mathrm{K}+1)-\mathrm{L}^{\prime}(\mathrm{K})\right|$; $\mathrm{D}: \Delta \mathrm{K}$ calculated as $\Delta \mathrm{K}=$ mean $\left|\mathrm{L}^{\prime \prime}(\mathrm{K})\right| / \mathrm{sd}[\mathrm{L}(\mathrm{K})]$. The modal value of this distribution is the most probable number of clusters or the uppermost level of structure, here three clusters. 


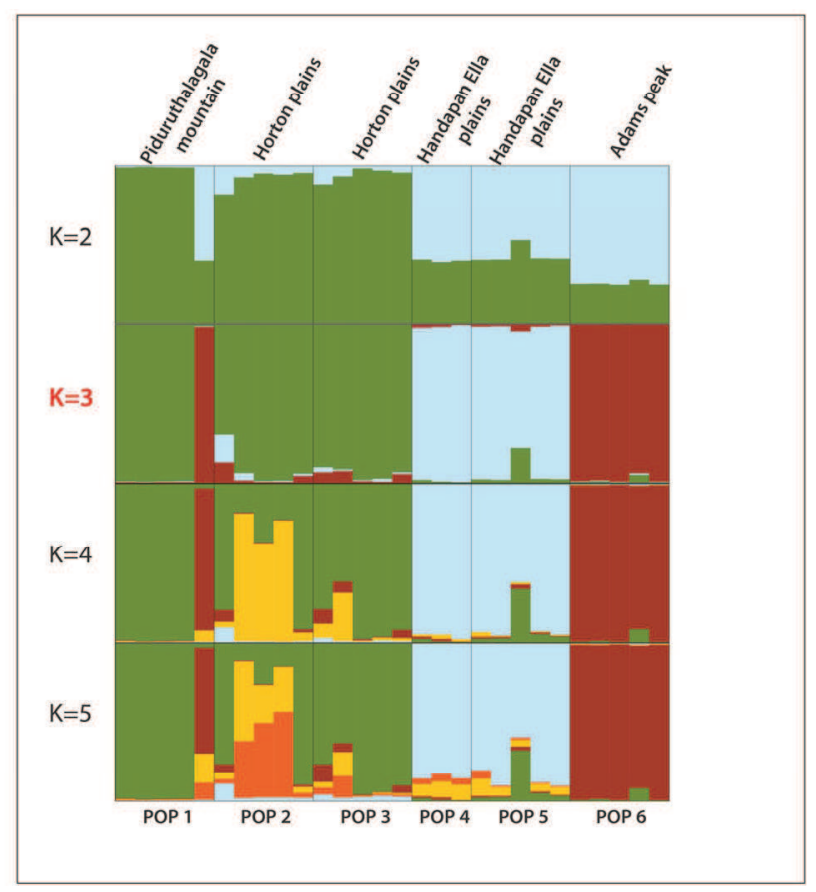

A

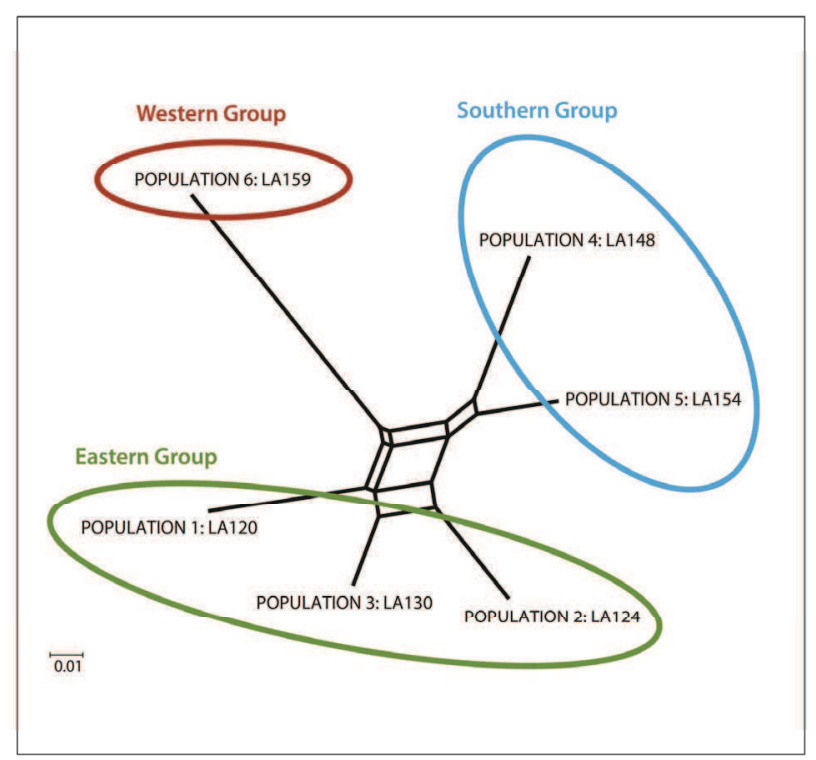

C

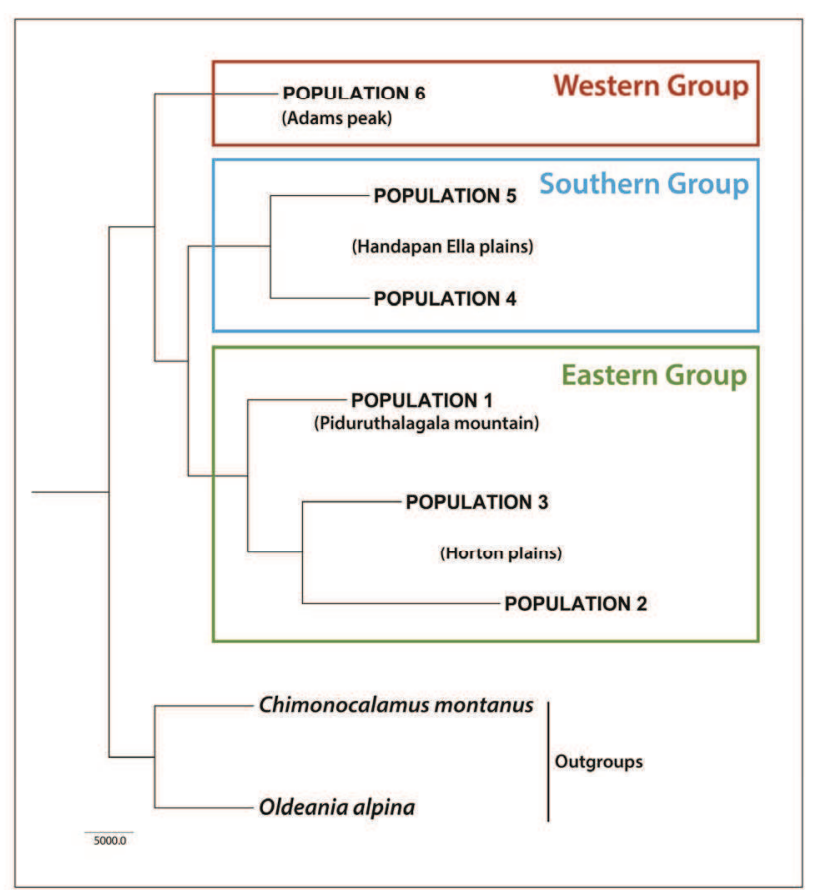

B

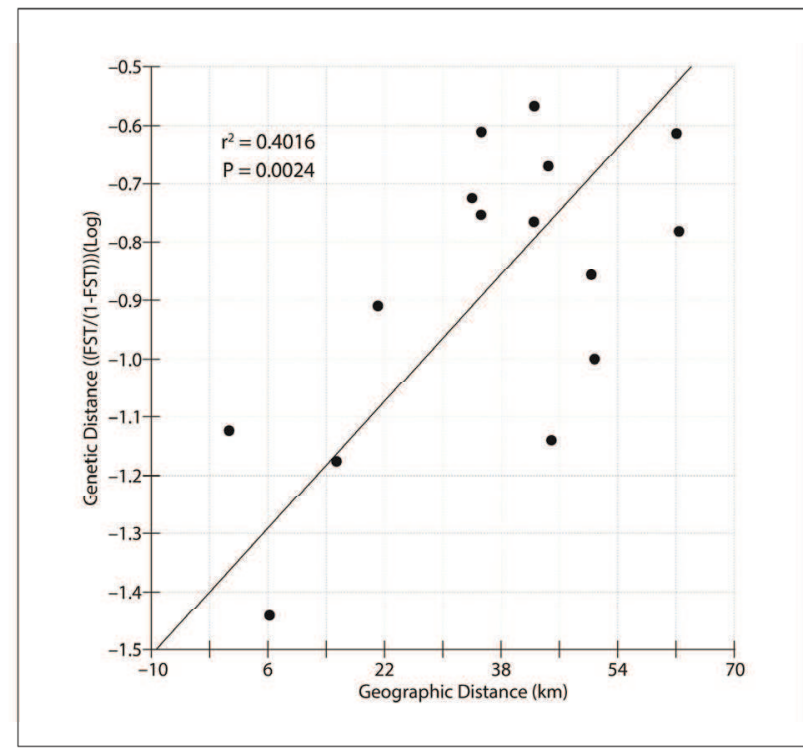

D

Figure 3: Analyses of genetic structure among the six K. debilis populations; A: Bayesian clustering using Structure for $\mathrm{K}=2-5$ putative genetic clusters. Each individual is represented by a vertical column and the populations are separated by a vertical black line. Different colours in the same column for each individual indicate the percentage of estimated membership in a cluster; B: rooted neighbour-joining (NJ) tree based on Cavalli-Sforza and Edwards' chord distance; C: neighbour-net network showing genetic relatedness among the study populations based on Cavalli-Sforza and Edward's chord distance; D: isolation by distance plot of Rousset's genetic differentiation on geographical distance $(\mathrm{km})$ 


\section{Genetic structure inferred from AMOVA and genetic distances}

Partitioning of genetic variability by AMOVA revealed that 8.35 and $7.52 \%$ of the total genetic variation was distributed among the $\mathrm{K}=3$ clusters recognised by Structure analysis, and among populations within these clusters, respectively. Both of these values were significantly greater than zero $(\mathrm{p}<0.001$; Table 5). The remaining ca. $84 \%$ of the variation was distributed among individuals within populations.

The Mantel test of the correlation between Rousset's genetic distance and geographic distance indicated strong and highly significant isolation by distance among the six $K$. debilis populations $\left(\mathrm{r}^{2}=0.4016 ; \mathrm{p}=0.0024\right)$ (Figure 3D).

\section{Genetic relationships within the geographic groups}

The rooted NJ tree for the six $K$. debilis populations (Figure 3B) resulted in three clades corresponding to the three genetic clusters indicated by the Structure analysis (Figure 3A). The neighbour-net network derived from the SplitsTree analysis also revealed the same three population genetic clusters (Figure 3C).

\section{DISCUSSION}

\section{Locus and population level genetic diversity}

Of the six $K$. debilis populations sampled for this study, population 1 (LA120), which was collected from mount Piduruthalagala was unusual in displaying lower allelic and genetic diversity compared to the other five populations (Table 3). The lower diversity of this population is not due to a smaller sample size or more missing loci, as these were similar to the other populations examined. The $2.7 \%$ of missing genotypes is due to failure to amplify certain loci.
Of the various dimensions of genetic diversity, allelic richness is often considered to be of key relevance in conservation programmes (Petit et al., 1998; Simianer, 2005; Foulley \& Ollivier, 2006). Allelic diversity is particularly sensitive to bottlenecks in population size and genetic drift, and may be an important indicator of a population's adaptive potential, as the limit of selection response is mainly determined by the initial number of alleles regardless of the allelic frequencies (Hill \& Rasbash, 1986). Based on these expectations, Petit et al. (1998) regarded allelic richness as the most informative measure of genetic variation for identifying populations for conservation. From this perspective, population 1 may be of lesser value for conservation than populations $2-6$.

Table 4: Individual locus and average F-statistic measures estimated across six populations of $K$. debilis

\begin{tabular}{llll}
\hline Locus & $\mathrm{F}_{\mathrm{IT}}$ & $\mathrm{F}_{\mathrm{IS}}$ & $\mathrm{F}_{\mathrm{ST}}$ \\
\hline Sasa500 & $0.417^{* * *}$ & $0.251^{* * *}$ & $0.221^{* * *}$ \\
Sasa718 & -0.012 & $-0.099^{* *}$ & $0.079^{* *}$ \\
Sasa11E & -0.039 & -0.103 & $0.058^{*}$ \\
FAN11 & $0.148^{* * *}$ & -0.006 & $0.153^{* * *}$ \\
FAN16 & $0.250^{* *}$ & 0.163 & 0.103 \\
FAN20 & $0.377^{* * *}$ & $0.312^{* * *}$ & $0.095^{*}$ \\
FAN21 & -0.009 & $-0.112^{* *}$ & $0.092^{* * *}$ \\
FAN26 & 0.082 & -0.055 & $0.130^{* * *}$ \\
FAN27 & 0.095 & $0.140^{*}$ & -0.053 \\
FAN28 & 0.043 & -0.013 & $0.055^{*}$ \\
FAN29 & $0.508^{* * *}$ & $0.414^{* * *}$ & 0.161 \\
FAN30 & $0.531^{* * *}$ & $0.225^{* *}$ & $0.394 * * *$ \\
Average & $\mathbf{0 . 1 8 3 * * *}$ & $\mathbf{0 . 0 7 8 * * *}$ & $\mathbf{0 . 1 1 3} * * *$ \\
\hline
\end{tabular}

$\mathrm{F}_{\mathrm{IT}}$ : fixation index as the global population; $\mathrm{F}_{\mathrm{IS}}$ : inbreeding coefficient in relation to subpopulations; $\mathrm{F}_{\mathrm{ST}}$ : inbreeding due to differentiation of subpopulations in the total population. Significance of average F-statistic estimates: $* * *$, and $* * *$ denote $\mathrm{p}$ values less than 0.05 , 0.01 , and 0.001 , respectively.

Table 5: AMOVA analysis of genetic differentiation among the $\mathrm{K}=3$ clusters recognised by Structure analysis and among populations within these clusters

\begin{tabular}{lccccccc}
\hline Source of variation & df & SSD & $\begin{array}{c}\text { Variance } \\
\text { components }\end{array}$ & $\begin{array}{c}\text { Percentage } \\
\text { of variance }\end{array}$ & $\Phi_{\text {ST }}$ & $\Phi_{\text {SC }}$ & $\Phi_{\text {CT }}$ \\
\hline Among clusters & 2 & 38.159 & 0.314 & 8.35 & & & \\
Among populations & 3 & 25.069 & 0.283 & 7.52 & & & \\
within clusters & & & & & & & \\
Within populations & 106 & 335.817 & 3.168 & 84.13 & $0.159 *$ & $0.082 * * *$ & $0.084 * * *$ \\
Total & 111 & 399.045 & 3.765 & & & \\
\hline
\end{tabular}

Significance of estimated phi-statistics (see text): * and *** denote $\mathrm{p}$ values less than 0.05 and 0.001 , respectively. 
Vekemans and Hardy (2004) surveyed fine-scale spatial genetic structure analyses in plant populations based on both allozymes and microsatellites and showed that, on average outcrossing species have a $\mathrm{F}_{\text {IS }}$ value of 0.014 . The global $\mathrm{F}_{\text {IS }}$ value of 0.078 (Table 4) obtained for $K$. debilis is significantly low and indicates that these populations are primarily outcrossing.

\section{Genetic structure of $K$. debilis populations}

Genetic differentiation among angiosperm populations arises due to a variety of factors. Factors associated with relatively low values of genetic differentiation include woody habit, outcrossing breeding systems and wind dispersal (Hamrick et al., 1992), all of which are characteristic of K. debilis. Based on Wright's (1978) qualitative guidelines for the interpretation of $\mathrm{F}_{\mathrm{ST}}$, the global value for $K$. debilis $\left(\mathrm{F}_{\mathrm{ST}}=0.113\right)$ obtained in this study is within the suggested range for moderate genetic differentiation (range: $0.05-0.15$ ). That said, it is rather high given the relatively close spatial proximity of the study populations. This study showed that $K$. debilis populations cluster into three genetically distinct subgroups in the central mountains of Sri Lanka: one specific to the East (populations LA120, LA124 and LA130), one specific to the South (populations LA148 and LA154) and a single unique population to the West (LA159). These groupings were evident from all three of the clustering analyses used (structure, neighbour joining, and neighbour-net). The observation that the number of genetic clusters being lower than the number of populations is indicative of partial barriers to gene flow, which may be either historical or ongoing (Vergara et al., 2014). Also consistent with this observation, the Mantel test shows that geographic distance explains $40 \%$ of the genetic distance between population pairs. This positive association between geographic distance and genetic distance suggests that migration rates between these $K$. debilis populations decrease with increasing distance as expected under an isolation by distance (IBD) model of gene flow (Wright, 1943).

\section{Conservation implications}

This analysis is the first study investigating the genetic diversity and structure of $K$. debilis from Sri Lanka, with samples from almost all known populations evaluated using microsatellite markers. Although several studies have previously quantified population level genetic variation in bamboos, none of them have related this variation to the conservation of bamboo populations or species (Ramanayake et al., 2007; Lalhruaitluanga \& Prasad, 2009; Mukherjee et al., 2010; Triplett \& Clark, 2010). Populations $2-5$ showed generally high levels of genetic diversity (Table 4). Population 2 (LA124) from the northern part of the Horton Plains showed the highest levels of $\mathrm{N}_{\mathrm{A}}, \mathrm{N}_{\mathrm{Ae}}$ and $\mathrm{A}_{\mathrm{R}}$, and is a particularly good candidate for conservation. The single population from Adams Peak (population 6: LA159) formed its own genetically distinct cluster and is also a potential candidate for conservation due to its unique genetic diversity. Although the three genetic clusters do not provide evidence for morphologically distinct ecotypes, their unique genetic diversity must be taken into consideration by conservation managers when identifying conservation management units. Many studies show that, while ecotypes do matter when defining management units, recommendations for conservation are commonly made based on the genetic uniqueness of the populations (Soule \& Simberloff, 1986; Barrett \& Kohn, 1991). As the six populations of $K$. debilis formed three genetically identifiable clusters, we recommend that populations separated by more than ca. $35 \mathrm{~km}$ (as is the case for these clusters) should be treated as distinct units for management and conservation, while those within ca. $15 \mathrm{~km}$ should be managed jointly. These recommendations serve as an initial step towards identifying management units for threatened bamboos in Sri Lanka. However, since our sample sizes are relatively smaller one must use these results cautiously.

Despite the small sample sizes, levels of genetic variation were found to be relatively high within individual populations. Further, tests of genetic differentiation among populations were found to be highly significant. Consequently, this study provides important insight into the genetic diversity and connectivity of $K$. debilis and is a significant initial step towards the conservation management of this threatened temperate woody bamboo species. For these rare and threatened species with limited distribution areas, a single stochastic event, such as a serious insect attack or pathogen infection, could cause catastrophic reductions in population size and genetic diversity, and even extinction (Ma et al., 2013). Taking proper measures to protect their current populations is required.

\section{Acknowledgement}

Field work was supported by the National Science Foundation of USA grant DEB-0515712 to Lynn G. Clark and the genotyping was funded by an Ecology, Evolution and Organismal Biology (EEOB) Finch Fund award in 2012 - 2013 and an EEOB graduate student research grant. The authors thank the Forest Department, Sri Lanka, the Department of Wildlife Conservation of Sri Lanka and Sri Lanka Customs for providing the necessary permits to collect and export both herbarium 
material and silica dried leaf material from Sri Lanka. We would also like to thank Mr. Nuwan De Silva and Mr. Abayapala De Silva for their generous help during fieldwork. A special thanks to Dr Hashendra Kathriarachchi for her collaboration. We also thank Mr. Arun Sethuraman for technical assistance.

\section{REFERENCES}

1. Abayasinghe K.R.K., Ranawana K.B., Gamage M.G.E. \& Nilanthi R.M.R. (2014). Change detection in vegetation cover of Horton plains national park for adaptive management: a practical geoinformatics approach. Journal of the Department of Wildlife Conservation 2: 113 - 131.

2. Attigala L., Kathriarachchi H.-S. \& Clark L.G. (2016). Taxonomic revision of the temperate woody bamboo genus Kuruna (Poaceae: Bambusoideae: Arundinarieae). Systematic Botany 41(1): 174 - 196. DOI: https://doi.org/10.1600/036364416X690570

3. Attigala L., Triplett J.K., Kathriarachchi H.-S. \& Clark L.G. (2014). A new genus and a major temperate bamboo lineage of the Arundinarieae (Poaceae: Bambusoideae) from Sri Lanka based on a multi-locus plastid phylogeny. PhytoTaxa 174(1): $187-205$.

DOI: https://doi.org/10.11646/phytotaxa.174.4.1

4. Bandaratillake H.M. \& Fernando M.P.S. (2003). National Forest Policy Review: Sri Lanka. An Overview of Forest Policies in Asia (eds. T. Enters, M. Qiang \& R.N. Leslie). Food and Agriculture Organisation, Bangkok, Thailand.

5. Barrett S. \& Kohn J. (1991). Genetic and evolutionary consequences of small population size in plants: implications for conservation. Genetics and Conservation of Rare Plants (eds. D.A. Falk \& K.E. Holsinger), pp. 3 - 30. Oxford University Press, New York, USA.

6. Cavalli-Sforza L.L. \& Edwards A.W.F. (1967). Phylogenetic analysis models and estimation procedures. The American Journal of Human Genetics 19: 233 - 257.

DOI: https://doi.org/10.2307/2406616

7. Clark L.G., Londoño X. \& Ruiz-Sanchez E. (2015). Bamboo taxonomy and habit. Bamboos, the Plant and its Uses (eds. W. Liese \& M. Köhl), pp. 1 - 30. Springer International Publishing, Switzerland.

8. DeWoody J., Nason J.D. \& Hipkins V.D. (2006). Mitigating scoring errors in microsatellite data from wild populations. Molecular Ecology Notes 6: 951 - 957.

DOI: https://doi.org/10.1111/j.1471-8286.2006.01449.x

9. De Zoysa N.D. \& Vivekanandan K. (1994). Field guide to the rattans of Sri Lanka. Forestry Information Service, pp. 83. Forest Department of Sri Lanka, 82, Rajamalwatta Road, Battaramulla.

10. Earl D.A. \& vonHoldt B.M. (2012). STRUCTURE HARVESTER: a website and program for visualizing STRUCTURE output and implementing the Evanno method. Conservation Genetics Resources 4(2): 359 - 361. DOI: https://doi.org/10.1007/s12686-011-9548-7

11. Ellstrand N.C. \& Elam D.R. (1993). Population genetic consequences of small population size: implications for plant conservation. Annual Review of Ecology and Systematics 24: 217 - 242.

DOI: https://doi.org/10.1146/annurev.es.24.110193.001245

12. Esselink G.D., Nybom H. \& Vosman B. (2004). Assignment of allelic configuration in polyploids using the MAC-PR (microsatellite DNA allele counting-peak ratios) method. Theoretical Applied Genetics 109: 402 - 408.

DOI: https://doi.org/10.1007/s00122-004-1645-5

13. Evanno G., Regnaut S. \& Goudet J. (2005). Detecting the number of clusters of individuals using the software STRUCTURE: a simulation study. Molecular Ecology 14: $2611-2620$.

DOI: https://doi.org/10.1111/j.1365-294X.2005.02553.x

14. Excoffier L., Laval G. \& Schneider S. (2005). Arlequin ver. 3.0: an integrated software package for population genetics data analysis. Evolutionary Bioinformatics Online 1: $47-50$.

15. Felsenstein J. (1989). PHYLIP - Phylogeny Inference Package (version 3.6). Cladistics 5: $164-166$.

16. Fischer M. \& Matthies D. (1998). RAPD variation in relation to population size and plant performance in the rare Gentianella germanica. American Journal of Botany 85: $811-819$.

DOI: https://doi.org/10.2307/2446416

17. Fischer M., Van Kleunen M. \& Schmid B. (2000). Genetic allele effects on performance, plasticity and developmental stability in a clonal plant. Ecology Letters 3: $530-539$. DOI: https://doi.org/10.1046/j.1461-0248.2000.00188.x

18. Food and Agriculture Organization of the United Nations (FAO) (2005). Global Forest Resources Assessment, Country Reports-Sri Lanka. FRA2005/123. Food and Agriculture Organization, Rome, Italy.

19. Forestry Sector Master Plan (FSMP) (1995). Forest Department, Ministry of Agriculture, Lands and Forestry, Sri Lanka.

20. Foulley J.L. \& Ollivier L. (2006). Estimating allelic richness and its diversity. Livestock Science 101: 150 - 158. DOI: https://doi.org/10.1016/j.livprodsci.2005.10.021

21. Government of Sri Lanka (2000). Initial National Communication under the United Nations Framework Convention on Climate Change. Colombo, Sri Lanka.

22. Gunatilake H.M. (1998). The role of rural development in protecting tropical rainforests: evidence from Sri Lanka. Journal of Environmental Management 53(3): 273 - 292. DOI: https://doi.org/10.1006/jema.1998.0201

23. Gunatilleke I.A.U.N. \& Gunatilleke C.V.S. (1990). Distribution of floristic richness and its conservation in Sri Lanka. Conservation Biology 4(1): 21 - 31 . DOI: https://doi.org/10.1111/j.1523-1739.1990.tb00262.x

24. Gunatilleke I.A.U.N., Gunatilleke C.V.S. \& Abeygunawardena P. (1994). An interdisciplinary research initiative towards sustainable management of forest resources in lowland rain forests of Sri Lanka. Journal of Sustainable Forestry 1(4): 95 - 114.

DOI: https://doi.org/10.1300/J091v01n04_05

25. Hamrick J.L., Godt M.J.W. \& Sherman-Broyles S.L. (1992). Factors influencing levels of genetic diversity in woody plant species. New Forests 6: $95-124$. DOI: https://doi.org/10.1007/BF00120641 
26. Hardy O. \& Vekemans X. (2002). SPAGeDi: a versatile computer program to analyze spatial genetic structure at the individual or population levels. Molecular Ecology Notes 2: $618-620$. DOI: https://doi.org/10.1046/j.1471-8286.2002.00305.x

27. Hill W.G. \& Rasbash J. (1986). Models of long term artificial selection in finite population. Genetic Research 48: $41-50$.

DOI: https://doi.org/10.1017/S0016672300024642

28. Hurlbert S.H. (1971). The nonconcept of species diversity: a critique and alternative parameters. Ecology 52: 577 586.

DOI: https://doi.org/10.2307/1934145

29. Huson D.H. \& Bryant D. (2006). Application of phylogenetic networks in evolutionary studies. Molecular Biology and Evolution 23(2): 254 - 267.

DOI: https://doi.org/10.1093/molbev/msj030

30. Jakobsson M. \& Rosenberg N.A. (2007). CLUMPP: a cluster matching and permutation program for dealing with label switching and multimodality in analysis of population structure. Bioinformatics 23: 1801 - 1806.

DOI: https://doi.org/10.1093/bioinformatics/btm233

31. Jensen J.L., Bohonak A.J. \& Kelley S.T. (2005). Isolation by distance, web service. BMC Genetics 6: 13. v.3.22. Available at $h t t p: / / i b d w s . s d s u . e d u /$, Assessed 12 June 2013.

32. Judziewicz E.J., Clark L.G., Londoño X. \& Stern M.J. (1999). American Bamboos, pp. 392. Smithsonian Institution Press, Washington DC, USA.

33. Kariyawasam D. (1998). Bamboo resources and utilization in Sri Lanka. In: Bamboo - conservation, diversity, ecogeography, germplasm, resource utilization and taxonomy. Proceedings of Training Course cum Workshop (eds. A.N. Rao \& R. Rao), Kunming and Xishuangbanna, Yunnan, China, 10 - 17 May, International Plant Genetic Resources Institute (IPGRI), Rome, Italy.

34. Kitamura K., Saitoh T., Matsuo A. \& Suyama Y. (2009). Development of microsatellite markers for the dwarf bamboo species Sasa cernua and Sasa kurilensis (Poaceae) in northern Japan. Molecular Ecology Resources 9(6): 1470 -1472 .

DOI: https://doi.org/10.1111/j.1755-0998.2009.02675.x

35. Lalhruaitluanga H. \& Prasad M.N.V. (2009). Comparative results of RAPD and ISSR markers for genetic diversity assessment in Melocanna baccifera Roxb. growing in Mizoram State of India. African Journal of Biotechnology 8: $6053-6062$.

DOI: https://doi.org/10.5897/AJB09.047

36. Luijten H., Dierick A., Oostermeijer J., Raijmann L. \& Den-Nijs H. (2000). Population size, genetic variation, and reproductive stress in rapidly declining, self-incompatible perennial (Arnica montana) in the Netherlands. Conservation Biology 14: 1776 - 1787. DOI: https://doi.org/10.1046/j.1523-1739.2000.99345.x

37. Ma Y.P., Chen G., Grumbine R.E., Dao Z.L., Sun W.B. \& Guo H.J. (2013). Conserving plant species with extremely small populations (PSESP) in China. Biodiversity and Conservation 22: 803 - 809 .

DOI: https://doi.org/10.1007/s10531-013-0434-3
38. Mukherjee A.K., Ratha S., Dhar S., Debata A.K., Acharya P.K., Mandal S., Panda P.C. \& Mahapatra A.K. (2010). Genetic relationships among 22 taxa of bamboo revealed by ISSR and EST-based random primers. Biochemical Genetics 48: 1015 - 1025.

DOI: https://doi.org/10.1007/s10528-010-9390-8

39. Muktesh Kumar M.S. (2011). Grasses and BamboosBamboos of Peninsular India, pp. 140. Kerala Forest Research Institute, Peechi, Kerala, India.

40. Nanayakkara V.R. (1996). Forests and Forestry in Sri Lanka: An Historical Perspective. Commonwealth Secretariat. UK.

41. Nielsen R., Tarpy D.R. \& Reeve H.K. (2003). Estimating effective paternity number in social insects and the effective number of alleles in a population. Molecular Ecology 12: $3157-3164$.

DOI: https://doi.org/10.1046/j.1365-294X.2003.01994.X

42. Paschke M., Abs C. \& Schmid B. (2002). Relationship between population size, allozyme variation, and plant performance in the narrow endemic Cochlearia bavarica. Conservation Genetics 3: $131-144$.

DOI: https://doi.org/10.1023/A:1015293530776

43. Petit R.J., El Mousadik A. \& Pons O. (1998). Identifying populations for conservation on the basis of genetic markers. Conservation Biology 12: 844 - 855.

DOI: https://doi.org/10.1046/j.1523-1739.1998.96489.x

44. Pluess A.R. \& Stocklin J. (2004). Genetic diversity and fitness in Scabiosa columbaria in the Swiss Jura in relation to population size. Conservation Genetics 5: 145 - 156. DOI: https://doi.org/10.1023/B:COGE.0000029999.10808.c2

45. Pritchard J.K., Stephens M. \& Donnelly P. (2000). Inference of population structure using multilocus genotype data. Genetics 155: 945 - 959.

46. Rajapakse M.C. (1992). Studies on the in vitro development of Dendrocalamus giganteus. M. Phil thesis, Postgraduate Institute of Agriculture, University of Peradeniya, Peradeniya.

47. Ramanayake S.M.S.D. \& Weerawardene T.E. (2003). Flowering in a bamboo, Meloccana (Bambusoideae: Poaceae). Botanical Journal of the Linnaean Society 143(3): $287-291$.

DOI: https://doi.org/10.1046/j.1095-8339.2003.00216.x

48. Ramanayake S.M.S.D. \& Yakandawala K. (1995). Some observations in the flowering in Dendrocalamus giganteus and Bambusa vulgaris. Proceedings of the $6^{\text {th }}$ Regional Workshop on Multipurpose Tree Species in Sri Lanka (ed. H.P.M. Gunasena), pp. 116 - 120, MPTS Research Network, Faculty of Agriculture, University of Peradeniya, Peradeniya.

49. Ramanayake S.M.S.D. \& Yakandawala K. (1998). Incidence of flowering, death and the phenology of the giant bamboo (Dendrocalamus giganteus Wall. Ex Munro). Annals of Botany 82(6): 779 - 785.

DOI: https://doi.org/10.1006/anbo.1998.0754

50. Ramanayake S.M.S.D., Meemaduma V.N. \& Weerawardene T.E. (2007). Genetic diversity and relationships between nine species of bamboo in Sri Lanka, using random amplified polymorphic DNA. Plant Systematics and Evolution 269: 55 - 61. 
DOI: https://doi.org/10.1007/s00606-007-0587-1

51. Ramanayake S.M.S.D., Wanniarachchi W.A.V.R. \& Tennakoon T.M.A. (2001). Axillary shoot proliferation and in vitro flowering in an adult giant bamboo, Dendrocalamus giganteus Wall. ex Munro. In vitro Cellular and Developmental Biology - Plant 37: 667 - 671.

DOI: https://doi.org/10.1007/s11627-001-0116-9

52. Rosenberg N.A. (2004). DISTRUCT: a program for the graphical display of population structure. Molecular Ecology Notes 4: 137 - 138.

DOI: https://doi.org/10.1046/j.1471-8286.2003.00566.x

53. Rousset F. (1997). Genetic differentiation and estimation of gene flow from F-statistics under isolation by distance. Genetics 145: 1219 - 1228.

54. Saltonstall K. (2003). Microsatellite variation within and among North American lineages of Phragmites australis. Molecular Ecology 12: 1689 - 1702.

DOI: https://doi.org/10.1046/j.1365-294X.2003.01849.x

55. Seethalakshmi K.K. \& Muktesh Kumar M.S. (1998). Bamboos of India-a Compendium, pp. 342. Bamboo Information Centre-India, Kerala Forest Research Institute, Peechi and International Network for Bamboo and Rattan, Beijing. Eindhoven, New Delhi.

56. Simianer H. (2005). Using expected allele number as objective function to design between and within breed conservation of farm animal biodiversity. Journal of Animal Breed Genetics 122: 177 - 187.

DOI: https://doi.org/10.1111/j.1439-0388.2005.00523.x

57. Soderstrom T.R. \& Calderón C.E. (1979). Ecology and phytosociology of bamboo vegetation. Ecology of Grasslands and Bamboo Lands of the World (ed. M. Numata), pp. 223 - 236. VEB Gustav Fisher Verlag, Jena, Germany.

58. Soule M. \& Simberloff D. (1986). What do genetics and ecology tell us about the design of nature reserves? Biological Conservation 35: 19 - 40.
59. Triplett J.K. \& Clark L.G. (2010). Phylogeny of the temperate woody bamboos (Poaceae: Bambusoideae) with an emphasis on Arundinaria and allies. Systematic Botany 35: $102-120$.

DOI: https://doi.org/10.1600/036364410790862678

60. Vergara R., Gitzendanner M.A., Soltis D. \& Soltis P. (2014). Population genetic structure, genetic diversity, and natural history of the South American species of Nothofagus subgenus Lophozonia (Nothofagaceae) inferred from nuclear microsatellite data. Ecology and Evolution 4(12): $2450-2471$.

DOI: https://doi.org/10.1002/ece3.1108

61. Vekemens X. \& Hardy O.J. (2004). New insights from finescale spatial genetic structure analyses in plant populations. Molecular Ecology 13: 921 - 935.

DOI: https://doi.org/10.1046/j.1365-294X.2004.02076.x

62. Wijesundara D.S.A., Kathriarachchi H.-S., Ranasinghe S.W. \& Hapuarachchi G. (2012). Analysis of seed plants of Sri Lanka. The National Red List 2012 of Sri Lanka: Conservation Status of the Fauna and Flora. Biodiversity Secretariat of the Ministry of Environment and the Department of National Botanic Gardens, Colombo and Peradeniya.

63. Wright S. (1943). Isolation by distance. Genetics 28: $114-138$.

64. Wright S. (1978). Evolution and the Genetics of Populations. Variability within and among Natural Populations, volume 4. University of Chicago Press, Chicago, USA.

65. Young A., Boyle T. \& Brown T. (1996). The population genetics consequences of habitat fragmentation for plants. Tree 11: $413-418$.

66. Zhan X.J., Wei F.W. \& Bruford M.W. (2009). 25 microsatellite loci for Fang's cane bamboo Bashania fangiana. Molecular Ecology Resources 9: 1460 - 1466. 